American University Washington College of Law

Digital Commons @ American University Washington College of

Law

Contributions to Books

Scholarship \& Research

2015

\title{
The FDA and the Rise of the Empowered Patient
}

Lewis Grossman

American University Washington College of Law, lewisg@wcl.american.edu

Follow this and additional works at: https://digitalcommons.wcl.american.edu/facsch_bk_contributions

Part of the Food and Drug Law Commons, Health Law and Policy Commons, and the Science and

Technology Law Commons

\section{Recommended Citation}

Grossman, Lewis, "The FDA and the Rise of the Empowered Patient" (2015). Contributions to Books. 107.

https://digitalcommons.wcl.american.edu/facsch_bk_contributions/107

This Book Chapter is brought to you for free and open access by the Scholarship \& Research at Digital Commons @ American University Washington College of Law. It has been accepted for inclusion in Contributions to Books by an authorized administrator of Digital Commons @ American University Washington College of Law. For more information, please contact kclay@wcl.american.edu. 


\title{
FDA and the Rise of the Empowered Patient
}

\author{
LEWIS A. GROSSMAN
}

AS RECENTLY as the I970s, patients played virtually no role in the U.S. Food and Drug Administration's (FDA's) process for approving drugs (Best 20I2; Carpenter 2004). The drug development and review process was the exclusive domain of government bureaucrats, scientific experts, and the pharmaceutical industry. Not coincidentally, the agency provided desperately ill patients with access to promising investigational drugs only occasionally, on an ad hoc basis.

Today highly organized and well-funded patient advocacy groups regularly seek to influence FDA's decisions regarding pharmaceutical products. The agency holds public meetings with patient advocates regarding drug development issues, includes them as "special government employees" in private preapproval discussions with manufacturers, and consults with them during internal agency review of drugs. Patients also regularly testify before FDA advisory committees, which often include a patient representative as a voting member. Both Congress and FDA explicitly acknowledge the importance of the patient's perspective with respect to risk-benefit analyses, and they have established programs to hasten the approval of important drugs and to 
provide early access to desperately needed unapproved drugs. The Food and Drug Administration Safety and Innovation Act of 2012 (FDASIA) reflects and requires this patient-centered ethos in various ways discussed in this chapter.

While the extent of patients' actual impact on FDA decision making remains unclear, they irrefutably wield much more influence than they did four decades ago. This chapter explores a constellation of trends and events that underlie this dramatic shift, examines the current role of patients in drug regulation, and considers the future of patientfocused drug development.

\section{THE CULTURAL FOUNDATION}

Various cultural developments of the past half century underlie the transformation of the American patient from a passive, uninformed recipient of medications into an active, knowledgeable participant in drug development and regulation.

\section{A. The Decline of Trust}

One critical trend has been the citizenry's declining trust in the leaders of major institutions, including those that formerly exercised exclusive control over the drug supply. This decay of confidence has driven patients to intervene in the drug regulatory process rather than passively accept the decisions of governmental and scientific experts.

A loss of faith in large institutions and professional expertise was one of the defining characteristics of the I970s (Berkowitz 2006; Schulman 2002; Carroll 2000), and Americans have remained skeptical about the motives and competence of "the establishment" ever since. Between the mid-I960s and I980, the percentage of poll respondents saying "you can trust" the leaders of various institutions plummeted with respect to all institutions considered, including the federal government, the medical profession, and major companies. Although the public's confidence has waxed and waned since I980, its trust level has never approached its mid-I960s peak (Harrisinteractive.com 20II; Website of American National Election Studies). FDA appears to have maintained the public's esteem longer than other institutions. Since 
the turn of the twenty-first century, however, confidence in the FDA has fallen precipitously, as well (Carpenter 20IO:I2, 749-50).

\section{B. The Rights Revolution}

The I970s have also frequently been identified as the period of the "rights revolution" (Berkowitz 2006:I33-57; Sandbrook 20I I:24950). Concepts like women's rights, gay rights, environmental rights, disability rights, and consumer rights dominated the national conversation. Another important aspect of the rights revolution that blossomed in the I970s was the notion of "patients' rights." The genesis of the patients' rights movement appears to have been the drafting in I970 of twenty-six such rights by the National Welfare Rights Organization. This action precipitated a widespread discussion that culminated in the adoption of a "Patient's Bill of Rights" in I973 by the American Hospital Association. This document, and indeed the entire patients' rights movement, was premised on the notion that patients would no longer simply accept the ministrations of a presumptively wise and beneficent medical system but would instead become active, informed agents in their own treatment. It is important to note that the patients' rights movement overlapped in significant ways with other rights movements - for example, those for disability rights, racial civil rights, women's rights, and-most importantly for this chaptergay rights.

The rights culture and rhetoric that coalesced in the I970s lived beyond it (Walker I998:33). One author argues that the rights revolution "survived the Reagan and Bush years unscathed and even enhanced" (Sandbrook 20II:250). This assertion is certainly true with respect to patients' rights.

\section{The Changing Health Information Environment}

Another noteworthy cultural development of the past several decades is the enormous increase in health information available to the general public. Although domestic health guides have existed throughout American history, until quite recently publishers did not seek a mass market for books containing technical information about the 
treatments administered and prescribed by physicians. This changed in I979, when Bantam released the first edition of The Pill Book, subtitled The Illustrated Guide to the Most Prescribed Drugs in the United States. Seventeen printings of the first edition totaled more than one million copies. Competitors, including the American Medical Association, soon offered their own volumes with similar information. For consumers not daunted by technical language, the Physicians' Desk Reference, containing the full physician package insert for every approved drug, became widely available in bookstores shortly after The Pill Book and was an immediate bestseller (Fleischer I98I).

Today, of course, the significance of printed books about prescription drugs pales in comparison to that of the Internet, which has made it easy for anyone with a computer or smartphone to find detailed medical information. During the I990s, thousands of health-oriented sites appeared on the new World Wide Web. Commercial websites that organized this universe of information for consumers began appearing in the late I990s. By 2007, 40 million unique users visited WebMD alone each month (Freudenheim 2007). Although advanced searchengine technology has since reduced the importance of such websites, American patients remain voracious (and in many instances, sophisticated) consumers of medical information (Duggan and Fox 2OI3).

Finally, patients today receive abundant information about prescription drugs directly from the manufacturers. As explored in detail elsewhere (Grossman 20I4), until the I980s, the typical consumer never saw labeling or advertising for any prescription drug, with the possible exception of the patient package insert for oral contraceptives. FDA traditionally believed (in agreement with physicians and industry) that consumers of prescription medications should be ignorant and passive beneficiaries of their doctors' care. However, a dramatic transformation in agency policies during the past several decades has led to a deluge of patient labeling and direct-to-consumer advertising of prescription drugs.

\section{THE RISE OF FOOD AND DRUG ACTIVISM}

The mass mobilizations of AIDS and breast cancer activists in the I980s are often identified as the pioneering models for modern patient activism (Carpenter 2004:58; Bix I997). But even these movements 
had precedents-campaigns in the I970s involving vitamin pills, saccharin, and Laetrile (an alternative cancer therapy). These earlier social movements, though not focused on conventional prescription drugs, demonstrated how organized citizens could successfully fight to preserve consumers' freedom to make their own risk-benefit judgments about FDA-regulated products.

In August I973, FDA issued a rule restricting the permissible combinations of nutrients in vitamin and mineral supplements 38 Fed. Reg. 20,723). The rule also declared that the agency would regulate high-potency supplements as drugs and, in some instances, prescription drugs. A health libertarian organization with right-wing propensities, the National Health Federation (NHF), was at the heart of the opposition, but the dissent blossomed into a genuine popular movement. The NHF choreographed a demonstration against "nutritional tyranny" in Washington. Its alarmist (and inaccurate) warnings that "the Government is going to take our vitamins away" triggered what the New York Times characterized as a "massive flow of letters" to Congress (Lyons I973). Vitamin deregulation was, along with Watergate, the energy crisis, and the economy, one of the four issues that generated the most mail to Congress in I973 ("Of Vitamins, Mineral: Fighting the FDA" I974).

In I974 testimony supporting Congressional intervention, the legislative counsel for a health food industry trade group voiced a regulatory philosophy that seemed to reflect the views of a broad swath of Americans: "As long as he is not dealing with dangerous or untruthfully labeled food, then risktaking [sic] should be for each man to decide for himself..." (Senate Subcommittee on Health I974). The next day, the U.S. Court of Appeals for the Second Circuit partially struck down FDA's vitamin and mineral regulation (National Nutritional Foods Ass'n v. FDA I974:76I). Two years later, Congresswithout a single dissenting vote-invalidated the remainder of the rule with the Vitamin-Mineral Amendments of I976 (90 Stat. 4OI, 4IO).

Another mass protest against FDA arose in response to the agency's April I977 proposal to revoke the interim food additive approval for saccharin, which was then the only artificial sweetener on the market (42 Fed. Reg. I9,996). After studies demonstrated saccharin's carcinogenicity in rats, the agency did not really have any discretion in the matter, for the Federal Food, Drug, and Cosmetic Act's (FDCA's) Delaney Clause states that "no additive shall be deemed to be safe 
if it is found to induce cancer when ingested by man or animal" (2 I USC $\$ 409(\mathrm{c})(3)(\mathrm{A}))$. After publishing the proposed rule revoking the approval, however, the agency reported that "the protest is stronger and louder than any response in recent history" (Winter I977). Outraged citizens included not only diabetics (and their physicians), but also millions of people who drank diet soda to limit caloric intake. A Harris survey found that Americans opposed the saccharin ban by 76 percent to I 5 percent (Harris I977).

As it had in the vitamin-mineral supplement controversy, Congress stepped in. By an overwhelming margin, it enacted legislation in I977 to suspend FDA's prohibition of saccharin while also mandating warnings of its carcinogenicity in animals (9I Stat. I45I). Senator Edward Kennedy queried: "If a substance has both benefits and risks, who should decide whether the risk should be taken-the Federal Government or the individual?” (I23 Cong. Rec. S29352 (Sept. I 5, I977)). He concluded, in light of saccharin's undoubted benefits and the division of opinion regarding its safety, that "the individual is in the best position to decide for himself or herself whether they [sic] want to expose themselves or their children to saccharin use."

At about the same time, the first-ever mass protest against FDA's refusal to permit marketing of a drug was gaining momentum. The product at issue was Laetrile (amygdalin), an alternative cancer treatment derived from apricot pits. Although Laetrile advocacy was formerly confined largely to right-wing extremists, the I 972 arrest of a California doctor who prescribed Laetrile "launched a significant SM [social movement]...as people from across the political spectrum united under the libertarian banner of medical freedom" (Hess 2005:522).

In May I977, FDA held court-ordered public administrative hearings to resolve questions regarding Laetrile's legal status. These hearings, jammed with rowdy Laetrile supporters, took on an almost riotous atmosphere (Young I992:224; "Laetrile Backers, Foes Clash at FDA Hearing" I977). Meanwhile, U.S. Representative Steven D. Symms, citing "grass roots support" stemming from outrage over the Laetrile situation, was promoting his "Medical Freedom of Choice Bill" (H.R. 54; "Legalize Laetrile as a Cancer Drug? Interview with Representative Steven D. Symms" I977). This law would have repealed the power FDA acquired in 1962 to review the efficacy as well as the safety of new drugs before marketing. The Symms bill gained at least 
IIO cosponsors in the House of Representatives (I23 Cong. Rec. I8752 (June I3, I977)). The Washington Post opined that the Laetrile matter was "already out of [the] control" of the "professionals" and "bureaucrats" (Editorial I977). Even the editor of the New England Journal of Medicine suggested that FDA legalize Laetrile to calm the "Laetrilomania" (Ingelfinger 1977).

In July 1977, a poll showed that 58 percent of Americans believed Laetrile should be sold legally, versus 28 percent who opined that it should remain illegal (The Roper Organization I977). In response to boisterous state legislative hearings and torrents of mail to lawmakers, half of the states passed Laetrile legalization statutes (Young I992:22I). The public's interest in the drug faded in the early I 980 s (Young I992:232-33), and the Laetrile campaign ultimately had no direct effect on federal food and drug regulation. Nonetheless, the Laetrile supporters showed how patient advocacy movements could shake FDA to its foundations - an important lesson for their successors, the AIDS activists.

\section{AIDS ADVOCACY}

With the terrifying spread of AIDS in the I980s, groups such as ACT UP, Project Inform, and the Gay Men's Health Crisis commenced an epic, ultimately successful struggle to shape FDA's decisions regarding drugs for the disease (Arno and Feiden I992; Carpenter 2010:42857; Epstein I996; Hilts 2003:236-54).

In I986, under pressure from AIDS groups, FDA made the unapproved investigational drug AZT available to patients outside of formal clinical trials on a "compassionate use" basis. The next year, FDA approved the new drug application (NDA) for AZT, despite the absence of large Phase 3 clinical investigations and experts' doubts regarding its safety and effectiveness. Less than two years elapsed between the submission of AZT's investigational new drug (IND) application and its NDA approval - an astonishingly brief period compared to most drugs. On the very same day in I987 that FDA approved AZT, it further responded to AIDS activists' demands by proposing a "Treatment IND" rule ( 52 Fed. Reg. 8850). This regulation, finalized two months later ( 52 Fed. Reg. I9466), permitted seriously ill people lacking satisfactory alternatives to gain access to investigational drugs that "may 
be effective," although this access was strictly limited to ensure that the drugs would also be tested in controlled clinical studies.

Despite these successes, the AIDS interest groups' victory was far from complete. Later in I987, an FDA advisory committee recommended against approving the NDA for ganciclovir, a promising treatment for a blindness-inducing viral infection common among people with AIDS. The AIDS groups, outraged by the committee's recommendation, threatened action. They became even more furious when FDA imposed extremely strict access restrictions on the treatment IND for another drug, trimetrexate. Following stormy congressional hearings, FDA surrendered and broadened the terms of the trimetrexate IND.

AIDS activists nonetheless feared that the agency would remain an obstinate barrier to early access to promising drugs. In September I988, ACT UP conducted a highly publicized symbolic takeover of FDA headquarters in suburban Maryland, protesting the agency's approach to ganciclovir, trimetrexate, and other treatments. The handbook for the action declared: "The FDA says it exists to protect consumers. Well, people with HIV are consumers too, and they need to be protected from a deadly disease" (Eigo I988).

After this demonstration, FDA seemed more responsive to the concerns of AIDS patients. Just eight days after the takeover, the agency promulgated an interim regulation, "Subpart E," which facilitated faster development and approval of drugs for life-threatening and severely debilitating diseases. Subpart E did so by guaranteeing drug companies early consultation on study design, authorizing NDA approvals based solely on Phase 2 trial results, and implementing a more flexible risk-benefit analysis that considered "the severity of the disease and the absence of satisfactory alternative therapy" (2I CFR 3 I2 Subpart E, \$ 3 I $2.84(\mathrm{a}))$.

The activists' success in influencing FDA policy became further apparent in connection with ddI, a drug closely related to AZT. In response to continuing pressure from the AIDS community, FDA embraced a "parallel track" approach to ddI, allowing patients who did not qualify for the ongoing Phase 2 trials of the drug to take it for treatment purposes if AZT did not help them. In I989, AIDS activists, with the assistance of FDA and National Institutes of Health (NIH) officials, persuaded ddI's manufacturer to make the drug available at no cost to these patients. FDA soon officially embraced the 
"parallel track" mechanism more generally (55 Fed. Reg. 20856 (May 2 I, I990); 57 Fed. Reg I3250 (April I 5, I992)). Moreover, in I99I, the agency approved the NDA for ddI before the completion of the Phase 2 trials, based on data showing efficacy in achieving surrogate endpoints (rather than longer survival). The next year, FDA formalized this approach, as well, when it promulgated its Accelerated Approval ("Subpart $\mathrm{H}$ ") regulations, which permit the approval of drugs for serious or life-threatening illnesses based on their effect on unvalidated surrogate endpoints reasonably likely to predict clinical benefit (2 I CFR 3 I4 Subpart H).

Congress subsequently incorporated many of the AIDS movement's demands into the FDCA itself. The Food and Drug Administration Modernization Act of I997 (FDAMA) (I I I Stat. 2296) codified FDA's Treatment IND rule, the Subpart E regulations (under the rubric "Fast Track"), and an expanded version of the Accelerated Approval rule (2 I USC $\$ \$ \$ 356,360 b b b)$.

\section{BEYOND AIDS}

The reform of FDA's drug approval system was only one of the AIDS movement's visible triumphs in the late I980s and early I990s. It also effectively lobbied NIH and Congress for dramatic increases in federal funding for research into the disease (Bix I997:78I). Other disease communities noticed the AIDS activists' achievements (along with breast cancer advocates' contemporaneous success in garnering federal research funds), and a spectacular proliferation of patient advocacy organizations occurred. Whereas some of these organizations were funded by the pharmaceutical industry, others represented only the interests of disease victims. The number of large, disease-focused nonprofits swelled from 400 at the beginning of the I990s to more than IOOO in 2003 (Best 2OI2:78I).

Today, following the model forged by the AIDS community, these disease groups regularly seek to sway FDA drug approval decisions. FDA advisory committee meetings, once technical affairs attended solely by scientists, bureaucrats, lawyers, and corporate officials, are now sometimes crowded with representatives of disease advocacy organizations, some of whom offer impassioned testimony. Moreover, patient advocates now often serve on the advisory committees themselves. 
Their presence is another legacy of the AIDS movement. In I99I, in response to activists' demands, FDA created a position for a patient representative on the Antiviral Drugs Advisory Committee for HIV (Food and Drug Administration 2OI 5 ). Inspired by this development, cancer organizations asked for similar representation on committees reviewing cancer-related therapies, and the Clinton Administration granted this request in I996 (Clinton \& Gore I996:9). ${ }^{\text {I }}$

Patients are now important and visible actors in the advisory committee process. Consider, for example, a September 2012 meeting of the Oncologic Drugs Advisory Committee concerning the neoadjuvant breast cancer drug Perjeta. Participants in the open public hearing session included both individual survivors and representatives of Facing Our Risk of Cancer Empowered (FORCE) and Breastcancer. org (Food and Drug Administration 20I3a). The committee itself included a voting patient representative, Debra Madden, a two-time cancer survivor. The advisory committee ultimately voted unanimously in favor of granting accelerated approval to Perjeta for patients with early stage breast cancer before surgery, and FDA followed this recommendation.

It is difficult to assess precisely how influential patient activities were to this and other NDA approvals. But in a few prominent instances, patient activism has unambiguously changed outcomes. For example, in response to protests by sufferers of irritable bowel syndrome, in 2002 FDA permitted the return to the market of Lotronex, a drug previously withdrawn because of occasional severe side effects. Moreover, statistical analyses, along with anecdotal and observational evidence, indicate that effective political and media campaigns by patient groups shorten FDA drug review times (Carpenter 2004:59-60). Furthermore, the accelerated approval and fast track procedures, which owe their very existence to patient activism, have been extremely useful in getting needed treatments to desperate patients more quickly.

Another indication of FDA's growing patient orientation in drug development is the agency's creation, in cooperation with the Critical Path Institute and the pharmaceutical industry, of a Patient-Reported Outcome (PRO) Consortium. This public-private initiative's mission-to evaluate and qualify PRO instruments for use as endpoints in clinical trials - is premised on the understanding that " $[\mathrm{m}]$ ore and more, it has been recognized that some assessments [of investigational medical products] might best be made by the patients themselves" 
(Food and Drug Administration 20IO). The consortium has held annual workshops since $20 \mathrm{IO}$.

The impact of patient activism on FDA regulation of drugs should not be overstated. For example, treatment INDs remain rare. Although this scarcity is due primarily to manufacturers' reluctance to participate in early access programs and not to any FDA hesitancy to authorize them (Groopman 2006), ${ }^{2}$ one reason for the industry's lack of enthusiasm is the severe restrictions the agency imposes on charging for investigational drugs (2 I CFR 3I2.8). In 2007, these restrictions survived a constitutional challenge brought by a patient advocacy group in the U.S. Court of Appeals for the District of Columbia Circuit (Abigail Alliance 2007).

Nevertheless, the patient activists of the I980s and I990s undeniably drove FDA to reconceive the essence of its mission. The agency embraced the task not only of protecting the public health by preventing the sale of dangerous products, but also of enhancing the public health by ensuring rapid access to useful remedies (Arno \& Feiden I992:109). In I997, Congress amended FDA's official mission statement to reflect this shift-listing health promotion before health protection (2 I USC $\$ \mathrm{IOO}_{3}(\mathrm{~b})$ ).

\section{A. Food and Drug Administration Safety and Innovation Act of 2012}

The Food and Drug Administration Safety and Innovation Act of 2012 (I26 Stat. 993) represents a further advance in the rise of a patient-centered ethos, especially in the way the statute mandates patient involvement in earlier stages of the drug development process. FDASIA adds a new section $569 \mathrm{C}$ to the FDCA, titled "Patient Participation in Medical Product Discussion" (2 I USC $\$$ 36obbb-8c). This section obligates FDA to "develop and implement strategies to solicit the views of patients during the medical product development process and consider the perspectives of patients during regulatory discussions." To this end, it specifically instructs FDA to encourage the participation of patient representatives in agency meetings with the sponsors of drug, device, and biologic applications. In addition, FDASIA adds a new "breakthrough therapy" designation to expedite development of drugs that may offer substantial improvement 
over existing therapies, expands the situations in which accelerated approval is available, and broadens the surrogate endpoints on which such approval can be based (2 I USC $\$ \$ 356($ a), (c)).

FDASIA has prompted FDA to embrace a broad initiative titled "Patient-Focused Drug Development." Title I of FDASIA, the Prescription Drug User Fee Amendments of 2OI2, binds FDA to detailed performance goals for 2OI 3 through 2017 set forth in a separate document (I26 Stat. 993, 996). The goals enunciated by FDA in this document promise to move patients ever closer to the center of federal drug regulation. Under the heading of "Enhancing Benefit-Risk Assessment in Regulatory Decision-Making," FDA commits not only to increasing its use of patient consultants in regulatory discussions about specific products but also to holding four meetings per year with patient advocates regarding various disease areas (Food and Drug Administration 2OI3b). In its September 2OI3 notice of this series of meetings, FDA explained: "Patients who live with a disease have a direct stake in the outcome of the review process and are in a unique position to contribute to weighing benefit-risk considerations that can occur throughout the medical product development process" ( $77 \mathrm{Fed}$. Reg. 58848, 58849).

As part of its patient-centered initiative, FDA has launched a program called the "FDA Patient Network" (Food and Drug Administration 20I5). Among other functions, this program educates consumers about the development and approval of medical products, announces advisory committee meetings, provides information about clinical trials and early access programs, and recruits volunteers to serve as patient representatives on advisory committees and within the product review divisions.

\section{THE FUTURE}

Further integration of patients into drug regulation presents both opportunities and challenges for FDA. Such measures are likely to boost the agency's reputation and public support, as they did in the I980s and I990s (Carpenter 20I0:398). But any respect and good faith so earned could quickly dissolve if the agency's eagerness to satisfy the demands of sympathetic patients were to result in a postapproval, Vioxx-type safety fiasco. FDA can mitigate this risk, however, 
through liberal and creative use of its power to approve drugs subject to a Risk Evaluation and Mitigation Strategy (REMS). FDA might also face continuing pressure from patient groups to tweak its early access programs to entice more manufacturers to participate in themperhaps by revisiting the current limits on charging for investigational drugs (2 I CFR 3 I 2.8). But if these programs become more widely used, FDA may struggle to preserve the integrity of pivotal controlled clinical trials. Overall, the agency may struggle to simultaneously satisfy patients and maintain its standing as the planet's "gold standard" gatekeeper for new drugs.

In addition, FDA must consciously strive to avoid devoting a disproportionate share of its limited resources to diseases endemic to populations with the wherewithal to support the most effective advocacy organizations. The AIDS movement was successful in part because it was dominated by a corps of middle-class, highly educated white men with experience in social movement tactics (Epstein I996:I2). Not all disease groups have these advantages. And the AIDS crisis notwithstanding, prioritizing a disease because it happens to be represented by well-funded and skillful advocates may be both unwise and unjust (Dresser 200I:79-83). Furthermore, FDA should not assume that the leaders of disease organizations necessarily represent their entire diverse constituencies (Dresser 200I). Finally, the agency should carefully assess the extent to which any particular disease group represents independent interests rather than those of industry backers.

Patient groups trying to shape drug regulation face challenges, too. First, they increasingly must reckon not only with FDA and NIH but also with the Center for Medicare and Medicaid Services (CMS). As the number of insured Americans rises, the coverage decisions of CMS are having a growing impact on patient access to particular drugs. Accordingly, patient activists are focusing more energy on this agency. For example, in 2OII, patient mobilization helped induce CMS to pledge to continue covering Avastin for breast cancer after FDA withdrew approval of the drug for that use. And in light of "stakeholder input"-including furious protest by patients-CMS in 20I4 withdrew a proposal to allow formulary limitations in Medicare Part D coverage for three classes of drugs (Pear 2OI4).

Another challenge to patient organizations arises from the increasing specificity of illness and treatment resulting from medical advances, particularly in genetics. What will happen to today's disease-based 
groups if growing knowledge about disorders, together with the rise of gene-based personalized medicine, fractures the unity, and perhaps even the coherence, of current disease classifications? Consider, for example, fibromyalgia and chronic fatigue syndrome-diseases of unknown, and perhaps variegated, etiologies. Each has its own national patient advocacy association, and each was the topic of one of the first "patient-focused drug development" meetings held by FDA. But one can easily imagine a future in which these syndromes disintegrate into multiple, distinct subtypes, each with its own organization. The path from the American Cancer Society (I9I3) to the Leukemia \& Lymphoma Society ( I 949) to the Lymphoma Foundation of America (I986) to the Cutaneous Lymphoma Foundation (I998) presents a model that, if expanded throughout the world of morbidity, could result in uncoordinated activism and intergroup competition. Disease advocacy groups, which have long shared certain overarching goals with respect to FDA policy, may start ferociously competing with each other for the agency's resources and attention the way they already vie for NIH funds.

Even as they confront these challenges, however, patients are unlikely ever to lose their hard-earned influential role in American drug regulation.

\section{NOTES}

This work is derived in part from an article previously published in the Administrative Law Review: Lewis A. Grossman. 20I4. "FDA and the Rise of the Empowered Consumer." Administrative Law Review 66: 627-77.

I. FDA gave these representatives full voting privileges later that year (Food and Drug Administration 20I5).

2. In 20I4, FDA stated that it had approved 99 percent of all expanded access requests since October 2009 (Silverman 20I4).

\section{REFERENCES}

Abigail Alliance v. Von Eschenbach, 495 F.3rd 695 (D.C. Cir. 2007) (en banc). Arno, Peter S. and Karyn L. Feiden. I992. Against the Odds: The Story of AIDS Drug Development, Politics, and Profit. New York: HarperCollins. 
Berkowitz, Edward. 2006. Something Happened. New York: Columbia University Press.

Best, Rachel Kahn. 20I2. "Disease Politics and Medical Research Funding: Three Ways Advocacy Shapes Policy." American Sociological Review 77:780-803.

Bix, Amy Sue. I997. "Diseases Chasing Money and Power: Breast Cancer and AIDS Activism Challenging Authority." Journal of Policy History 9: 5-32.

Carpenter, Daniel P. 2004. "The Political Economy of FDA Drug Review: Processing, Politics, and Lessons for Policy." Health Affairs 23:52-63.

Carpenter, Daniel. 20IO. Reputation and Power: Organizational Image and Pharmaceutical Regulation at the FDA. Princeton: Princeton University Press.

Carroll, Peter N. 2000. It Seemed Like Nothing Happened: The Tragedy and Promise of America in the I970s. I982. Reprint. New Brunswick, N.J.: Rutgers University Press.

Clinton, Bill and Al Gore. I996. Reinventing the Regulation of Cancer Drugs. National Performance Review.

Dresser, Rebecca. 200I. When Science Offers Salvation: Patient Advocacy and Research Ethics. New York: Oxford University Press.

Duggan, Maeve, and Susannah Fox. 2013. "Health Online 2013." Pew Research Internet Project (January I 5 ).

Editorial. I977. "Why Not a Laetrile Bill." Washington Post (May 22).

Eigo, Jim et al. FDA Action Handbook, September I2, I988. Available on ActUp website.

Epstein, Steven. I996. Impure Science: AIDS, Activism, and the Politics of Knowledge. Berkeley: University of California Press.

Fleischer, Leonore. I98I. "Letter from New York: Getting to the Top." Washington Post (April I9).

Food and Drug Administration. 20IO. "The Patient Reported Outcomes (PRO) Consortium.” (November I). http://www.fda.gov/AboutFDA /PartnershipsCollaborations/PublicPrivatePartnershipProgram/ucm23 I I 29 .htm.

Food and Drug Administration. 20I 3a. "Oncologic Drugs Advisory Committee Meeting Transcript." (September I2). http://www.fda.gov/downloads /AdvisoryCommittees/CommitteesMeetingMaterials/Drugs/Oncologic DrugsAdvisoryCommittee/UCM3777 I4.pdf.

Food and Drug Administration. 2013b. "PDUFA Reauthorization Performance Goals and Procedures, Fiscal Years 2OI 3 through 20 I 7." http://www .fda.gov/downloads/ForIndustry/UserFees/PrescriptionDrugUserFee /UCM2704I2.pdf.

Food and Drug Administration. 20 I 5. "About the FDA Patient Network." http://www.fda.gov/forpatients/about/default.htm 


\section{FDA in a Changing World}

Freudenheim, Milt. 2007. "AOL Founder Hopes to Build New Giant Among a Bevy of Health Care Web Sites." New York Times (April I6).

Groopman, Jerome. 2006. "The Right to a Trial: Should Dying Patients Have Access to Experimental Drugs?" The New Yorker (December I 8), 40-47.

Grossman, Lewis. 20I4. "FDA and the Rise of the Empowered Consumer." Administrative Law Review 66: 627-77.

Harris, Louis. I977. "76 Per Cent [sic] Majority Opposes Ban on Saccharin." Chicago Tribune (April 2I).

Harrisinteractive.com. 20I I. "Confidence in Congress and Supreme Court Drops to Lowest Level in Many Years." (May I8).

Hess, David J. 2005. "Technology- and Product-Oriented Movements: Approximating Social Movement Studies and Science and Technology Studies." Science, Technology, and Human Values 30:5 I 5-35.

Hilts, Philip J. 2003. Protecting America's Health: The FDA, Business, and One Hundred Years of Regulation. New York: Alfred A. Knopf.

Ingelfinger, F. J. I977. "Laetrilomania." New England Journal of Medicine 296: I I67-68.

"Laetrile Backers, Foes Clash at FDA Hearing." I977. Washington Post (May 3), at $\mathrm{A}_{4}$.

"Legalize Laetrile as a Cancer Drug? Interview with Representative Steven D. Symms.” I977. U.S. News and World Report (June I3), 5 I.

Lyons, Richard D. I973. "Disputed Health Lobby Is Pressing for a Bill to Overturn Any Limits on Sales of Vitamins." New York Times (May I4).

National Nutritional Foods Ass' $n$ v. FDA, 504 F.2d 76I (2nd Cir. 1974).

"Of Vitamins, Minerals: Fighting the FDA." I974. Washington Post (January 20).

Pear, Robert. 20I4. "White House Withdraws Plan Allowing Limits to Medicare Coverage for Some Drugs." New York Times (March 20), at AI3.

Sandbrook, Dominic. 2OI I. Mad as Hell: The Crisis of the I97os and the Rise of the Populist Right. New York: Anchor Books.

Schulman, Bruce J. 2002. The Seventies: The Great Shift in American Culture, Society, and Politics. Cambridge, Mass.: De Capo Press.

Senate Subcommittee on Health, Senate Committee on Labor and Public Welfare. I974. (August I4).

Silverman, Ed.20I 4. "The FDA Says It's More Compassionate Than You Think." Corporate Intelligence Blog, Wall Street JournalOnline(May 5). http://blogs .wsj.com/corporate-intelligence/20I4/05/05/the-fda-says-its-more -compassionate-than-you-think/.

The Roper Organization. I977. "Roper Reports 77-7" (July 9-I6).

Walker, Samuel. I998. The Rights Revolution: Rights and Community in Modern America. New York: Oxford University Press. 
Website of American National Election Studies. "Trust the Federal Government I958-2008." http://www.electionstudies.org/nesguide/toptable/tab5a _I.htm.

Winter, Christine. I977. "Bitter Days Ahead? Consumers Protest Life sans Saccharin." Chicago Tribune (March I7).

Young, James Harvey. I992. American Health Quackery. Princeton: Princeton University Press. 